\title{
Erratum to: The Structural, Superconducting and Transport Properties of the Compounds $\mathrm{Y}_{3} \mathrm{Ba}_{5} \mathrm{Cu}_{8} \mathrm{O}_{18}$ and $\mathrm{Y}_{3} \mathrm{Ba}_{5} \mathrm{Ca}_{2} \mathrm{Cu}_{8} \mathrm{O}_{18}$
}

Ali Osman Ayaş • Ahmet Ekicibil • Selda Kılıç Çetin • Atilla Coşkun • Ali Oğuz Er • Yüksel Ufuktepe • Tezer Fırat • Kerim Kıymaç

Published online: 9 July 2011

(C) Springer Science+Business Media, LLC 2011

Erratum to: J Supercond Nov Magn

DOI 10.1007/s10948-011-1192-7

The name of Ali Oğuz Er, one of the co-authors of this article has been misprinted as Ali Osman Er.

The online version of the original article can be found under doi:10.1007/s10948-011-1192-7.

A.O. Ayaş

Department of Physics, Faculty of Sciences and Letters,

Adiyaman University, 02040, Adiyaman, Turkey

A. Ekicibil ( $\varangle) \cdot$ S.K. Çetin · Y. Ufuktepe · K. Kıymaç Department of Physics, Faculty of Sciences and Letters, Cukurova University, 01330 Adana, Turkey

e-mail: ahmetcan@cu.edu.tr

\section{A. Coşkun}

Department of Physics, Faculty of Sciences and Letters, Mugla

University, 48000, Mugla, Turkey

A.O. Er

Department of Physics, Old Dominion University, Norfolk, VA, 23529, USA

T. Firat

SNTG Laboratory, Physics Engineering Department, Hacettepe

University, 06800, Ankara, Turkey 